\title{
Year-round pesticide contamination of public sites near intensively managed agricultural areas in South Tyrol
}

\author{
Caroline Linhart ${ }^{*}$, Simona Panzacchi ${ }^{2}$, Fiorella Belpoggi ${ }^{2}$, Peter Clausing ${ }^{3}$, Johann G. Zaller ${ }^{4^{*}}$ \\ and Koen Hertoge ${ }^{1}$
}

\begin{abstract}
Background: In a previous study, we found that $45 \%$ of public playgrounds near intensively managed agricultural areas were contaminated with mainly endocrine active pesticide residues in spring. Here, we investigated potential contamination over the course of a year.

Methods: Residue data were analyzed from 96 grass samples collected in spring, summer, autumn, and winter by the South Tyrolean Medical Service in 19 public playgrounds, four schoolyards, and one marketplace located within intensively managed agricultural landscapes. Samples were analyzed for 281 substances using gas-chromatography and mass-spectrometry.

Results: A total of 32 pesticide residues and one preservative agent were found. Almost all of the sites (96\%) were contaminated with at least one residue during the year; in $79 \%$ of the sites, more than one residue was found. Among the detected residues, $76 \%$ are classified as endocrine active substances, with the highest concentrations of the insecticide chlorpyrifos-methyl $\left(0.71 \mathrm{mg} \mathrm{kg}^{-1}\right)$, the herbicide oxadiazon $\left(0.64 \mathrm{mg} \mathrm{kg}^{-1}\right)$, and the fungicides captan $\left(0.46 \mathrm{mg} \mathrm{kg}^{-1}\right)$ and fluazinam $\left(0.23 \mathrm{mg} \mathrm{kg}^{-1}\right)$. The number of residues, their concentrations, and the proportion of contaminated sites varied across seasons ( $p<0.001)$. Twenty-five residues were found in $83 \%$ of the sites in spring (median concentration $\left.0.240 \mathrm{mg} \mathrm{kg}^{-1}\right)$, nine in $79 \%$ of the sites in summer $\left(0.092 \mathrm{mg} \mathrm{kg}^{-1}\right)$, three in $50 \%$ of the sites in autumn $\left(0.076 \mathrm{mg} \mathrm{kg}^{-1}\right)$, and four in $17 \%$ of the sites in winter $\left(0.155 \mathrm{mg} \mathrm{kg}^{-1}\right)$. Playgrounds already examined in 2017 in the previous study, were more often contaminated with multiple pesticide residues in $2018(p=0.045)$.

Conclusion: This study confirms previous findings of widespread pesticide contamination of public sites within intensively managed agricultural areas. Moreover, pesticide residues were also found in periods with little or no pesticide application in the field (autumn and winter). It is worrisome that many of the detected residues are endocrine active substances and that some of them (thiacloprid, bupirimate, captan, folpet) are "suspected human carcinogens", according to EU authorities. Thus, we call for more effective controls of pesticide applications to minimize pesticide drift into public places.
\end{abstract}

Keywords: Agrochemicals, Non-target area, Pesticide drift, Exposure, Seasonal variation, Intensive agriculture, Apple production, Vineyards, Endocrine active substances, Maximum residue levels (MRL)

\footnotetext{
*Correspondence: linhart_caroline@hotmail.com; johann.zaller@boku.ac.at

1 Pesticide Action Network Europe, 67 Rue de la Pacification,

1000 Brussels, Belgium

${ }^{4}$ Institute of Zoology, University of Natural Resources and Life Sciences

Vienna (BOKU), Gregor Mendel Straße 33, 1180 Vienna, Austria

Full list of author information is available at the end of the article
}

\section{Highlights}

- Grass samples from 24 public sites in South Tyrol (Italy) were contaminated with a total of 32 pesticides and one preservative agent.

\section{Springer Open}

(c) The Author(s) 2020, corrected publication 2021. This article is licensed under a Creative Commons Attribution 4.0 International License, which permits use, sharing, adaptation, distribution and reproduction in any medium or format, as long as you give appropriate credit to the original author(s) and the source, provide a link to the Creative Commons licence, and indicate if changes were made. The images or other third party material in this article are included in the article's Creative Commons licence, unless indicated otherwise in a credit line to the material. If material is not included in the article's Creative Commons licence and your intended use is not permitted by statutory regulation or exceeds the permitted use, you will need to obtain permission directly from the copyright holder. To view a copy of this licence, visit http://creativecommons.org/licenses/by/4.0/. 
- At least one residue was found at $96 \%$ of the sites across all seasons of a year; more than one residue was found at $79 \%$ of the public sites.

- Fungicides (fluazinam, captan) were most abundant; $76 \%$ of the residues were classified as endocrine active, among them the insecticide chlorpyrifos.

- Contamination was highest in spring, with a maximum residue load of $0.96 \mathrm{mg} \mathrm{kg}^{-1}$. Some of the pesticide concentrations measured exceeded European maximum residue levels for food.

\section{Background}

Worldwide pesticide use is constantly increasing from $0.49 \mathrm{~kg} \mathrm{ha}^{-1}$ cropland in 1961 to $2 \mathrm{~kg} \mathrm{ha}^{-1}$ in 2004 [1]. It is expected that in 2020 global use of pesticide active ingredients will reach about 3.5 million tons $[2,3]$. This trend results in a continuous increase in the environmental pesticide load and thereby the risk of human exposure via water, air, soil, and food [1,4-6].

Due to a high proportion of pesticide-intensive fruit and wine production, Italy's pesticide use is about four times higher than the European average [7-9]. The Italian Trentino-Alto Adige Region and the Autonomous Province of Bolzano-South Tyrol report for 2018 an average use of $24.1 \mathrm{~kg} \mathrm{ha}^{-1}$ for fungicides, $13.0 \mathrm{~kg} \mathrm{ha}^{-1}$ for insecticides/acaricides, and $0.8 \mathrm{~kg} \mathrm{ha}^{-1}$ for herbicides, while the country-wide averages for Italy in 2018 were $3.55 \mathrm{~kg} \mathrm{ha}^{-1}, 0.6 \mathrm{~kg} \mathrm{ha}^{-1}$ and $0.88 \mathrm{~kg} \mathrm{ha}^{-1}$, respectively [10]. Moreover, due to the limited availability of cultivable and habitable land in the mountainous province of Bolzano-South Tyrol, apple orchards and vineyards often directly border on public places such as playgrounds, parks, schools, or private gardens [11]. Hence, the amount of non-target pesticide contamination in public places has been shown to correlate with the distance to apple orchards and their proportion in the landscape [12]. However, drift and atmospheric degradation of pesticides also depend on the physico-chemical properties of the pesticide product, droplet size during spray applications, and meteorological conditions during and after spraying [12-16].

Knowing the pesticide contamination of playgrounds is important as they are often visited by children or pregnant women, who are considered particularly vulnerable [17]. Our previous finding, that most of the pesticides detected at playgrounds in South Tyrol are endocrine active (EDA) or endocrine-disrupting chemicals (EDC) [12] is worrisome because EDAs and EDCs affect the hormone balance of fetuses, children, and teenagers [1821]. Moreover, residents living near agricultural areas with intensive pesticide use have been shown to develop several health deficiencies, including asthma, confusion, anxiety, weakness, problems with speaking and orientation, poor memory, frequent urination, and increased salivation [22]. Chronic pesticide exposure can also affect the neurological and behavioural development in children resulting in altered reflexes, attention deficit hyperactivity, and psychomotor and neurological development disorders [5, 23]. Importantly, even low levels of pesticide exposure over years can affect children's development, health, and behavior $[23,24]$.

In a previous study, we already demonstrated the diffuse low-level exposure of playgrounds during springtime [12], but it is unclear if exposures remain for the rest of the year. The present study thus aimed to assess year-round exposure levels of public sites in the Italian province of Bolzano-South-Tyrol, which is among the leading apple- and wine-producing areas in Europe [25].

We hypothesized that: (i) higher pesticide exposure would mainly occur in spring and summer when pesticides are actually applied, while in autumn and winter less to no pesticide residues would be expected [26]; (ii) public sites closer to intensively managed agricultural fields would be more often and higher contaminated than sites further away, and that (iii) pesticide contamination levels would be similar in spring 2017 and spring 2018.

These hypotheses were tested using data of residue levels of public sites across agricultural landscapes over the course of a year collected and analysed by regional authorities.

\section{Materials and methods}

\section{Sampling and site description}

After surveys in 2016 [27] and 2017 [12, 28], the Department of Environmental Medicine of the South Tyrolean Medical Service (Departement für Gesundheitsvorsorge - Betriebliche Sektion für Umweltmedizin des Südtiroler Sanitätsbetriebs) conducted in 2018 a further survey on residue contamination in the Autonomous Province Bolzano-South Tyrol (Italy). For the current study, these data were courteously provided by the South Tyrolean Medical Service.

Sites were selected and sampled by trained staff of the regional authority in 17 rural municipalities. The agricultural production areas included mainly apple orchards, vineyards, grasslands, and fields with vegetable crops. The samplings included 19 playgrounds, four schoolyards, and one public market place, and are referred to hereafter as public sites. Sampling was conducted between May 2018 and March 2019 on four sampling dates (spring, summer, autumn, and winter) making up a total of 96 samples. Fourteen of these playgrounds were already investigated in the previous study in spring 2017 [12]. 
In accordance with our previous results [12], sampled public sites were classified by their distance from the closest apple orchards and vineyards, hereafter called risk sites with $<100 \mathrm{~m}$ distance and control sites with $\geq 100 \mathrm{~m}$ distance. The distance was measured from the center of the sample site to the first agricultural plants of the agricultural sites. The final site selection included 7 sites in the Vinschgau Valley, 8 in the Etsch Valley, 6 in the Lower Etsch Valley, and 3 in the Eisack Valley, resulting in a total of $20(83.3 \%)$ risk sites and $3(12.5 \%)$ control sites. For one site no distance could be assessed due to unclear measurement. Geographical data obtained from the regional geographic information system Geobrowser (Autonomous Province Bozen/Bolzano-South Tyrol, 2017), included elevation and distance to the nearest orchards. To relate residue levels to precipitation amount within 5 days prior to sampling, data were obtained from the nearest meteorological stations [29].

Further, current results were compared with maximum residue limits (MRL) of lettuce, spinach and strawberries, based on the EU MRL database [30]. This quantitative evaluation was chosen because we assumed that similar numbers and amounts of residues would be detected in vegetables and fruits growing in private gardens and farms located at equal distances from agricultural areas as the investigated public sites [30].

\section{Sampling and laboratory analysis}

Access to the 96 laboratory reports including information on sampling and analysis was granted upon official request for "General Citizen Access" at the office for Institutional Affairs of the Autonomous Province of Bolzano-South Tyrol [31] on 14th December 2019.

Concretely, per site, a minimum of five selected grass samples was taken as representative of the sample site and grouped into one composite sample of about 300$400 \mathrm{~g}$ fresh mass [12]. Sampling was conducted 4 times between May 2018 and March 2019: first in spring 2018 between May and June, second in July 2018 (pre-harvest time), third in late summer/autumn 2018 between August and October (harvest time), and fourth in winter between January and March 2019, when no pesticide application is assumed [26, 32].

Plant material was analyzed by the official and accredited Laboratory for Food Analysis and Product Safety of the Autonomous Province of Bolzano-South Tyrol (Landesagentur für Umwelt und Klimaschutz - Labor für Lebensmittelanalysen und Produktsicherheit). Briefly, after acetonitrile extraction (701881-acetonitril for LCMS, ITW Reagents PanReac AppliChem) according to the dispersive SPE-QuEChERS-method [33], residue concentrations of grass samples were analyzed using a triple quadrupole GC/MS series system (Agilent 7000C,
Waldbronn, Germany) and API $4000^{\mathrm{TM}} \mathrm{LC}-\mathrm{MC} / \mathrm{MS}$ series system (AB Sciex, Concord ON, Canada), following the European standards UNI EN 15662:2009 and 15662:2018 [34], to identify up to 281 substances. Measured residue concentrations were based on the wet weight of fresh grass samples. Only active compounds were analyzed; no account was taken of metabolites and adjuvants [12, 35]. Unfortunately, the official list for pesticide monitoring performed by the South Tyrolean authorities did not include the frequently used herbicide glyphosate. However, neonicotinoid insecticides such as thiacloprid and imidacloprid were included.

\section{Statistical analyses}

Continuous variables were presented as medians with IQR (interquartile range) and categorical variables as percentages. Descriptive statistics and univariate test statistics were performed using RStudio (Version 1.3.1073) [36] including the packages doBy, psych, jtools, PMCMR, dplyr and tigerstats [37-42]. Chi-squared test and Fisher's exact test were applied for the discrete variable number of detected pesticides and independent 2-group Mann-Whitney- $U$ test for zero-inflated continuous data on residue concentrations between risk sites and control sites, and between contaminations of spring 2017 and spring 2018. The Kruskal-Wallis test and, if major effects were found, post hoc test for multiple comparisons of mean rank sums (Nemenyi test) were used to compare residue data among the four different sampling dates. Bonferroni correction method for multiple testing was used for post-hoc pairwise tests of continuous data (Nemenyi test) and for multidimensional contingency tables of count data.

The sum of rainfall $(\mathrm{mm})$ was calculated for a 5-day period before the sampling date and correlated with the number and concentration of fungicides. A two-sided $p$ value of $<0.05$ was considered statistically significant.

The distance categories "near" $(<100 \mathrm{~m})$ and "far" $(\geq 100 \mathrm{~m})$ were first computed-in accordance with our previous results-and additionally for the terciles of the distance measurements. Differences in medians of the distance groups were analysed with Wilcoxon ranksum tests with continuity correction respectively with Kruskal-Wallis rank-sum test for the three distance categories.

\section{Results}

In total, across all study sites and seasons, we found 32 pesticides and one preservative agent (2-phenylphenol). The detected pesticides across all four sampling sites included 24 fungicides, seven insecticides, and one herbicide (Table 1). In 23 of the 24 sites, at least one pesticide was detected over the entire year. In particular, over the 
Table 1 Characteristics of residues detected in the current study: Pesticide category and active ingredient, substance class, frequency of detection (Freq.) and maximum concentration (Max. conc.) in current samples, categorisations regarding carcinogenicity (Carc.), endocrine disruptor/activity (EDC), volatility and predicted mean dissipation half-life ( $\mathrm{HL}$; upper $\mathrm{Cl}$ for residues with wide $\mathrm{HL}$ ranges in brackets)

\begin{tabular}{|c|c|c|c|c|c|c|c|}
\hline $\begin{array}{l}\text { Pesticide category/ } \\
\text { detected residue }\end{array}$ & Substance class & Freq. & $\begin{array}{l}\text { Max. conc. } \\
\left(\mathrm{mg} \mathrm{kg}^{-1}\right)\end{array}$ & Carc. [56] & $\operatorname{EDC}^{a}[94,95]$ & Volatility $^{\mathbf{b}}[94]$ & $H L^{c}[59]$ \\
\hline \multicolumn{8}{|l|}{ Herbicides } \\
\hline Oxadiazon & Oxidiazole & 1 & 0.64 & - & Cat1 & Low & 3 \\
\hline \multicolumn{8}{|l|}{ Insecticides } \\
\hline Chlorpyrifos & Organophosphate & 2 & 0.71 & - & Cat3 & Low & 4 \\
\hline Chlorpyrifos-methyl & Organophosphate & 4 & 0.06 & - & Cat2 & Low & 3 \\
\hline Imidacloprid & Neonicotinoid & 5 & 0.03 & - & Cat3 & Low & $4(29)$ \\
\hline Methoxyfenozide & Diacylhydrazine & 5 & 0.03 & - & Cat2 & Low & 7 \\
\hline Phosmet & Organophosphate & 8 & 0.68 & - & Cat3 & Low & 2 \\
\hline tau-Fluvalinate & Pyrethroid & 1 & 0.01 & - & Cat3 & Low & 3 \\
\hline Thiacloprid & Neonicotinoid & 2 & 0.01 & 2 & Cat3 & Low & 4 \\
\hline \multicolumn{8}{|l|}{ Fungicides } \\
\hline Ametoctradin & Triazolopyrimidine & 1 & 0.01 & - & - & Low & - \\
\hline Boscalid & Carboxamide & 1 & 0.04 & - & Cat1 & Low & 7 \\
\hline Bupirimate & Pyrimidinol & 1 & 0.03 & 2 & Cat3 & Low & - \\
\hline Captan & Phthalimide & 22 & 0.46 & 2 & Cat3 & Low & 5 \\
\hline Cyflufenamid & Amidoxine & 2 & 0.01 & - & - & Low & - \\
\hline Cyprodinil & Anilinopyrimidine & 3 & 0.02 & - & Cat3 & Low & 6 \\
\hline Difenoconazole & Triazole & 10 & 0.12 & - & Cat3 & Low & 5 \\
\hline Diphenylamine & Amine & 2 & 0.51 & - & - & Low & - \\
\hline Dodine & Guanidine & 12 & 0.23 & - & - & Low & 3 \\
\hline Fluazinam & Phenylpyridinamine & 19 & 0.24 & - & Cat2 & Low & $4(69)$ \\
\hline Fludioxonil & Phenylpyrrole & 9 & 0.04 & - & Cat3 & Low & 5 \\
\hline Fluxapyroxad & Pyrazolium & 4 & 0.09 & - & - & Low & - \\
\hline Folpet & Phthalimide & 5 & 0.15 & 2 & Cat3 & Low & 5 \\
\hline Meptyldinocap & Dinitrophenol & 5 & 0.15 & - & Cat2 & Low & 3 \\
\hline Penconazole & Triazole & 3 & 0.04 & - & Cat3 & Low & 8 \\
\hline Penthiopyrad & Carboxamide & 2 & 0.10 & - & Cat2 & Low & - \\
\hline Propiconazole & Triazole & 1 & 0.05 & - & Cat2 & Low & 5 \\
\hline Pyraclostrobin & Strobilurin & 1 & 0.01 & - & Cat3 & Low & 4 \\
\hline Pyrimethanil & Anilinopyrimidine & 1 & 0.03 & - & Cat3 & Low & 5 \\
\hline Quinoxyfen & Quinoline & 2 & 0.02 & - & - & Low & $6(110)$ \\
\hline Spiroxamine & Morpholine & 1 & 0.02 & - & Cat2 & Low & 10 \\
\hline Tebuconazole & Triazole & 1 & 0.04 & - & Cat1 & Low & 8 \\
\hline Tetraconazole & Triazole & 1 & 0.01 & - & Cat1 & Low & 5 \\
\hline Zoxamid & Benzamide & 1 & 0.02 & - & Cat3 & Low & - \\
\hline \multicolumn{8}{|l|}{ Preservative agent } \\
\hline 2-phenylphenol & Phenole & 1 & 0.02 & - & - & High & - \\
\hline
\end{tabular}

No data available/not listed ="-"

${ }^{a}$ ED category 1: confirmed in animal studies, ED category 2: in-vitro study confirmed, ED category 3: endocrine active or potential disruptive, according to the structure of chemical substance and biochemical properties

b Renewal Assessment Reports (RARs) including vapor pressures documented by the Reporting Member State in the process of EU approval for pesticides

c Mean predicted dissipation $\mathrm{HL}$ for residues were rounded to full days. Additionally, very high maximum HLs ( $>25$ days) are listed in brackets 
course of the year, 20 sites showed at least one instance of contamination with 2-3 residues, (4 of these sites more than once a year) and 11 sites were contaminated with 4 or more residues. A maximum of 11 residues was detected at a playground in the Lower Etsch Valley in the village of Neumarkt in a $40 \mathrm{~m}$ distance from an agricultural field. One playground in Leifers (Marconistrasse) was located $25 \mathrm{~m}$ from an agricultural field and was contaminated with at least one pesticide the entire year. Only one playground in the city of Bolzano (playground Firmian) located at $40 \mathrm{~m}$ distance from an agricultural field showed no pesticide contamination at any of the sampling events.

The pesticides detected most frequently were the fungicides captan (one site in spring, 12 in summer, and 9 in autumn), followed by fluazinam (7 sites in spring and 12 in summer), dodine (two in spring, 10 in summer), and difeconazole (10 sites in spring). The highest concentrations were found for chlorpyrifos-methyl $\left(0.71 \mathrm{mg} \mathrm{kg}^{-1}\right)$, oxadiazon (0.64 $\left.\mathrm{mg} \mathrm{kg}^{-1}\right)$, captan $\left(0.46 \mathrm{mg} \mathrm{kg}^{-1}\right)$ and fluazinam $0.23 \mathrm{mg} \mathrm{kg}^{-1}$ ) (Table 1 ).

The majority of the detected residues (76\%, 25 out of 33) are classified as endocrine active (EA) substances: in particular, 4 pesticides belong to category 1 (endocrine disruptor ED as confirmed in animal studies [43-45]; 7 belong to category 2 (ED in vitro confirmed); and 15 are endocrine active substances or potential EDs belonging to category 3 (potential EA according to chemical structure and biochemical properties). Only 7 (21\%) of the detected residues are without any known endocrine activity [1, 43, 46] (Table 1).

Summarized concentrations of all EA substances on the investigated public sites were up to $1.12 \mathrm{mg} \mathrm{kg}^{-1}$ per grass sample, with a mean of $0.34 \mathrm{mg} \mathrm{kg}^{-1}$ (Table 2).

\section{Seasonal pesticide contamination}

Pesticide contamination of sites differed significantly among the four seasons. The percentage of contaminated si tes $(83 \%)$ and the number of detected residues (25 out of 33, Figs. 1, 2 and Additional file 1: Table S1) were significantly higher $(p<0.001)$ in spring compared to the other seasons. Median residue concentration was also higher in spring $\left(0.24 \mathrm{mg} \mathrm{kg}^{-1}, \mathrm{IQR}=0.28 \mathrm{mg} \mathrm{kg}^{-1}\right.$,

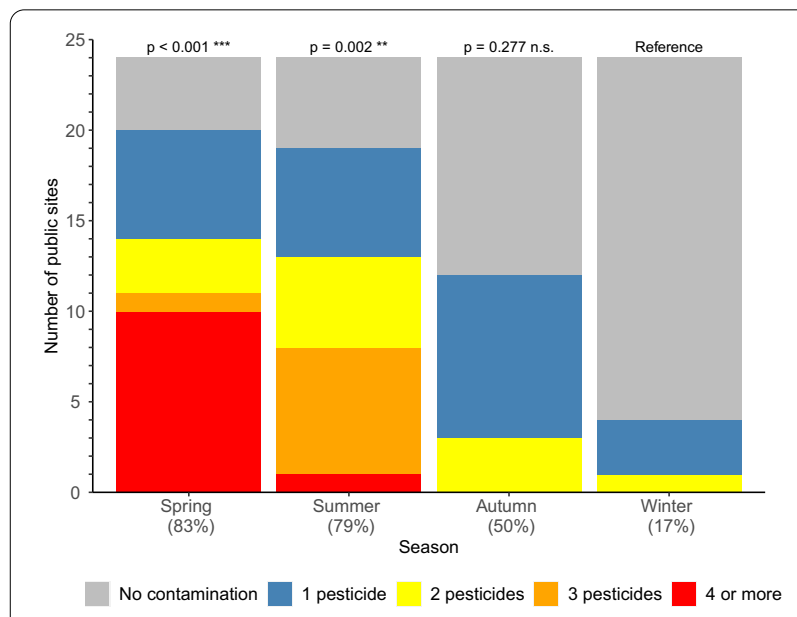

Fig. 1 Number of public sites with residue contamination for each season. Percentage of contaminated sites for each season in parenthesis ( $N=24$ sites per season). $p$-values denote differences in relation to the winter season as reference (Fishers-exact test with Bonferroni correction)

$\max =0.96 \mathrm{mg} \mathrm{kg}^{-1}$ ), but did not differ significantly from other seasons when including only the contaminated samples ( $p=0.128$, Kruskal-Wallis test, 2). However, including all samples, the seasons spring, summer and autumn differed significantly in pesticide load compared to residue loads detected in winter (Additional file 1: Table S2).

Over the course of a year, repeated contamination was observed for seven sites: On three sites decreasing concentrations of fluazinam were detected from spring to summer; five sites showed rising concentrations of captan from summer to autumn and one site had similar concentrations of dodine in spring and summer. Two sites showed repeated contamination with several residues mainly with captan and fluazinam or fluazinam and dodine (Fig. 3).

\section{Distance from agricultural sites}

Total median pesticide concentration was not significantly higher at public sites $<100 \mathrm{~m}$ distance from agricultural fields (median $0.02 \mathrm{mg} \mathrm{kg}^{-1}$, IQR $0.1 \mathrm{mg} \mathrm{kg}^{-1}$,

Table 2 Pesticide loads ( $\mathrm{mg} \mathrm{kg}^{-1}$ grass) on contaminated public sites per season

\begin{tabular}{|c|c|c|c|c|c|c|c|c|}
\hline \multirow[t]{2}{*}{ Parameter } & \multicolumn{2}{|c|}{ Spring $\left(N_{\mathrm{C}}=20\right)$} & \multicolumn{2}{|c|}{ Summer $\left(N_{\mathrm{C}}=19\right)$} & \multicolumn{2}{|c|}{ Autumn $\left(N_{\mathrm{C}}=12\right)$} & \multicolumn{2}{|c|}{ Winter $\left(N_{\mathrm{C}}=4\right)$} \\
\hline & Med. (IQR) & Max & Med. (IQR) & Max & Med. (IQR) & Max & Med. (IQR) & Max \\
\hline Pesticide load & $0.24(0.28)$ & 0.96 & $0.09(0.13)$ & 0.52 & $0.08(0.07)$ & 0.21 & $0.01(0.03)$ & 0.09 \\
\hline Fungicide load & $0.18(0.21)$ & 0.4 & $0.09(0.05)$ & 0.52 & $0.08(0.07)$ & 0.21 & $0.01(0.04)$ & 0.09 \\
\hline EDA load & $0.21(0.25)$ & 0.94 & $0.08(0.13)$ & 0.51 & $0.08(0.07)$ & 0.21 & $0.01(0.03)$ & 0.09 \\
\hline
\end{tabular}

Medians (Med.), Interquartile range (IQR) and maximum concentrations (Max), $N=24$ sites per season. No differences in concentrations for the contaminated sites across the four seasons were found. Including all sites, the seasons, spring and summer differ significantly from concentrations detected in winter 


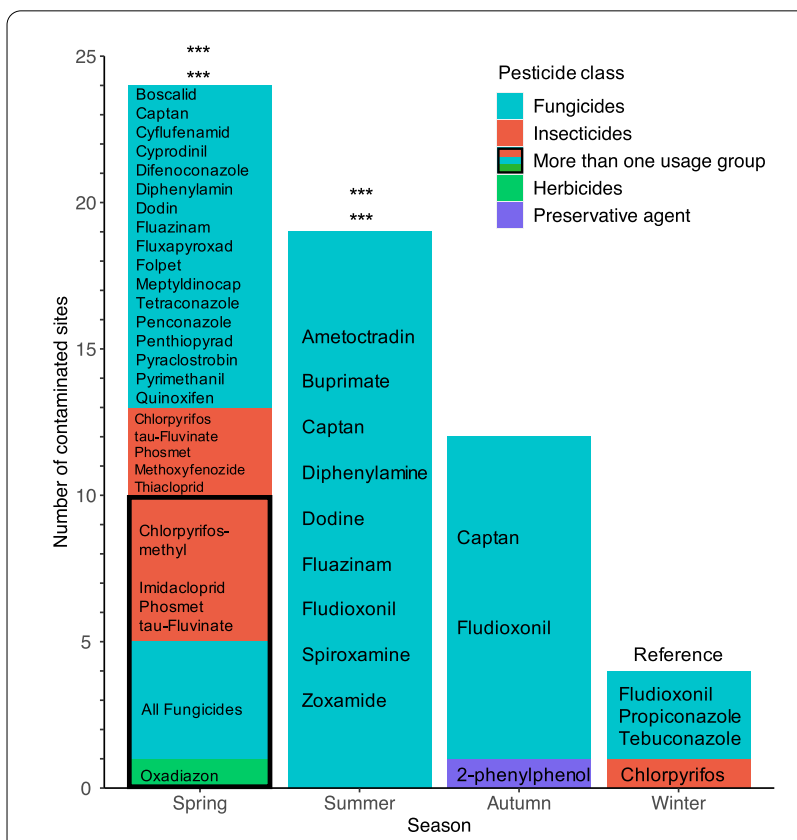

Fig. 2 Number of contaminated sites with different pesticide classes (and preservative agent) in the four seasons. Names of detected residues across all sites within a season are listed for each pesticide class; not all residues were found at each site. Total number of residues $=33$. Significance values ${ }^{* *}$ ( $p<0.001$, adj. Fisher's exact for multiple comparisons across seasons and within seasons) denote the difference between the total number of residues and number of EDA residues for spring and summer compared to winter

$n=20$ ) compared to sites $>100 \mathrm{~m}$ away (median $0.0 \mathrm{mg} \mathrm{kg}{ }^{-1}$, IQR $0.04 \mathrm{mg} \mathrm{kg}^{-1}, n=3$, Wilcoxon ranksum test with continuity correction, $p=0.156$ ). There was also no difference between medians of pesticide loads for the tercile categorization (15-30 m, 31-40 m, 41-600 m) (Additional file 1: Figures S1 and S2).

\section{Pesticide contamination of playgrounds in spring 2017 versus spring 2018}

Both, in spring 2017 and spring 2018, 12 out of 14 investigated playgrounds were contaminated. However, in spring 2018 significantly more playgrounds were contaminated with multiple pesticides than in spring 2017 $(p=0.045$, Fig. 4). The median number of contaminated playgrounds was also significantly higher in spring 2018 (median $=3.5, \mathrm{IQR}=4.8, \max =11$ ) as in spring 2017 (median $=2, \mathrm{IQR}=1.8, \max =4$, paired Mann-Whitney $U, p=0.01)$. Considering particular pesticides, more playgrounds were contaminated with difenoconazole in spring 2018 (7 sites) than in spring 2017 (1 site, Fisher'sexact test, $p=0.033$, Additional file 1: Table S6). Also, the concentration of fluazinam was higher in spring 2018 (med. $=0.19, \mathrm{IQR}=0.07$ ) than in spring 2017 (med $=0.03, \mathrm{IQR}=0.04$, Mann-Whitney $U, p=0.039$ ).

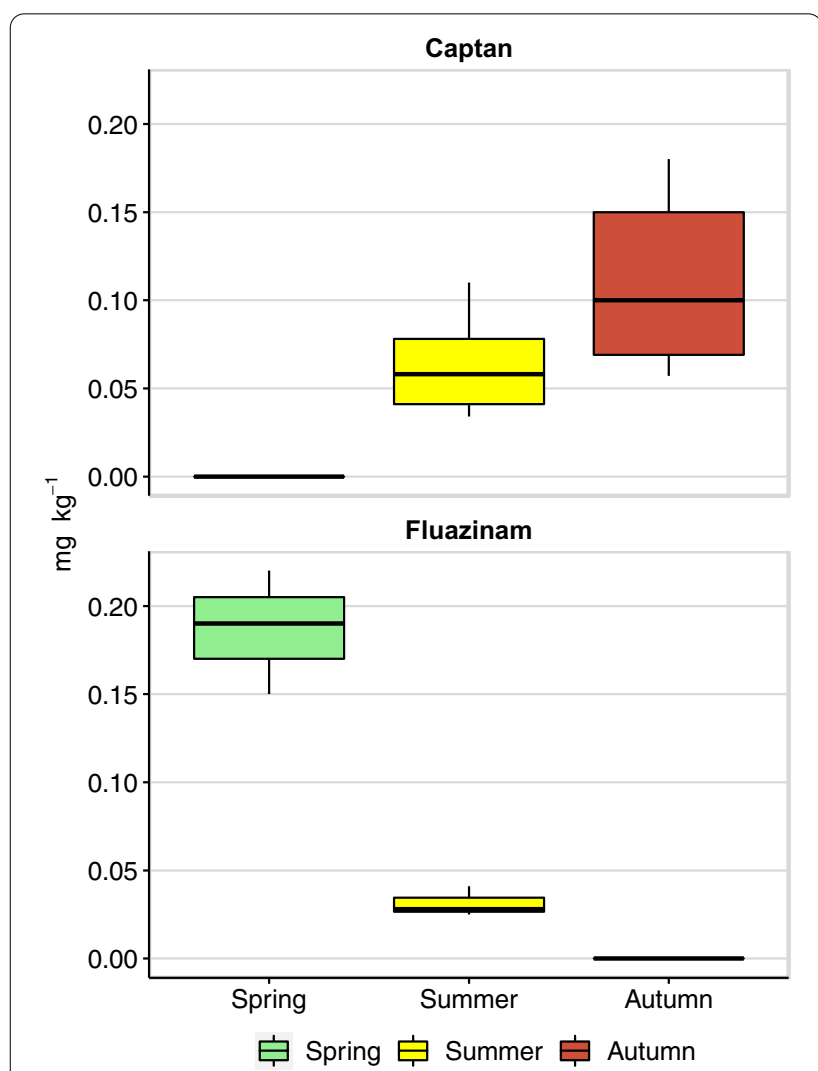

Fig. 3 Contamination of sites with residues of the fungicides captan and fluazinam among seasons. Captan was found on five sites, fluazinam on three sites. No contamination of these fungicides was found in winter

Total pesticide load $\left(\mathrm{mg} \mathrm{kg}^{-1}\right)$ did not differ significantly between years.

The amount of rainfall 5 days before sampling in spring 2018 (median $=10.6$, IQR $=10.9$ ) was higher than in spring 2017 (median $=5.8, \mathrm{IQR}=7.8$ ) but the difference was not significant $(p=0.069)$. Pesticide concentration across sites did not significantly correlate with the amount of rainfall (Pearson correlation, $r=0.11$, $p=0.063)$.

\section{Comparison of residues in grass to MRLs in vegetables and fruits}

Current residue levels were compared with MRLs for food items typical for home gardens-lettuce, spinach, and strawberries [30]. Comparing the residues found in the grass samples with the MRLs for these three food items, the MRLs for chlorpyrifos would have been exceeded up to 71-fold, for fluazinam up to 24-fold, for dodine up to 23-fold, for captan up to 15-fold, for folpet up to fivefold and for meptyldinocap up to threefold (Table 3). 


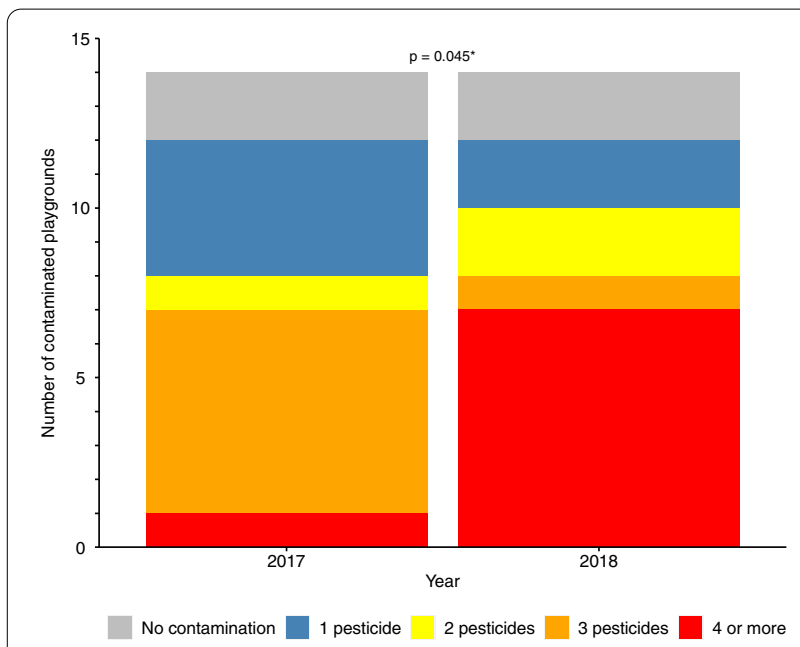

Fig. 4 Pesticide contamination of playgrounds investigated in spring 2017 and in spring 2018. Shown are stratified contaminations with single or multiple residues. In both years, 12 out of 14 playgrounds were contaminated. $p$-value denotes the difference between overall contamination based on number of residues (Fisher's exact test)

\section{Discussion}

To the best of our knowledge, the present study and our previous one [12] are the first to demonstrate pesticide contamination of public sites in agricultural landscapes using grass samples. For soil samples, pesticide contamination of playgrounds was reported in one European
[17] and one US study [47]. The US study [47] exclusively focused on residues of persistent organochlorine pesticides which have been banned since the 1970s, while the European study performed on playgrounds in Sarajevo [17] investigated also the variety of contaminants reported for public sites in South Tyrol. The soil samples of these studies were contaminated with up to 42 different pesticide residues with concentrations up to $0.1 \mathrm{mg} \mathrm{kg}^{-1}$ soil for Europe and up to $0.06 \mathrm{mg} \mathrm{kg}^{-1}$ for playgrounds in the USA [17, 47]. We argue that pesticide residues of grass samples might give a more immediate picture of actual pesticide contamination and off-site drift than soil samples due to possible faster degradation of residues on the surface. Our previous study showed that irradiance can be a driving factor to lower pesticide contamination by photodegradation $[12,48,49]$.

Concerning pesticide classes and concentrations, the findings of the current study are comparable with an Austrian study sampling field margins near apple orchards [50] showing that $73 \%$ of the detected residues were fungicides, the dominant pesticide class used in intensive apple and wine production. Furthermore, 23 of the detected residues reported in our current study were also detected in a recent monitoring study in Germany using passive air samplers which analyzed $>500$ substances in 116 sites across Germany [51]. Because glyphosate was the only pesticide found in all German sites we assume that glyphosate might also be present at our study sites

Table 3 Maximum residues (MR in $\mathrm{mg} \mathrm{kg}^{-1}$ ) in grass samples of frequently detected pesticides and surrogate maximum residue limits (MRL) according to EU database [30], assuming similar contamination levels for vegetables and fruits from home gardens

\begin{tabular}{|c|c|c|c|c|c|}
\hline \multirow[t]{2}{*}{ Pesticide } & \multirow[t]{2}{*}{ Current MR (grass) } & \multicolumn{3}{|c|}{ MRL according to EU database [30] } & \multirow{2}{*}{$\begin{array}{l}\text { Relationship } \\
\text { to lowest } \\
\text { surrogate MRL }\end{array}$} \\
\hline & & Lettuce & Spinach & Strawberry & \\
\hline Chlorpyrifos & 0.71 & 0.30 & 0.01 & 0.01 & 71-fold over \\
\hline Fluazinam & 0.24 & 0.05 & 0.01 & 0.01 & 24-fold over \\
\hline Dodine & 0.23 & 0.01 & 0.01 & 0.01 & 23-fold over \\
\hline Captan & 0.46 & 0.03 & 0.03 & 5.00 & 15-fold over \\
\hline Oxadiazon & 0.64 & 0.05 & 0.05 & 0.05 & 13-fold over \\
\hline Chlorpyrifos-methyl & 0.06 & 0.06 & 0.01 & 0.01 & Sixfold over \\
\hline Folpet & 0.15 & 0.03 & 0.03 & 1.50 & Fivefold over \\
\hline Penconazole & 0.04 & 0.01 & 0.01 & 0.50 & Fourfold over \\
\hline Meptyldinocap & 0.15 & 0.05 & 0.05 & 3.00 & Threefold over \\
\hline Phosmet & 0.07 & 0.05 & 0.05 & 0.05 & 1.4-fold over \\
\hline Imidacloprid & 0.03 & 2.00 & 0.05 & 0.05 & 1.7-fold under \\
\hline Difenoconazole & 0.12 & 3.00 & 2.00 & 0.40 & Threefold under \\
\hline Penthiopyrad & 0.10 & 15.00 & 30.00 & 3.00 & 30-fold under \\
\hline Fluxapyroxad & 0.09 & 4.00 & 3.00 & 4.00 & 33-fold under \\
\hline Methoxyfenozid & 0.03 & 4.00 & 4.00 & 2.00 & 67-fold under \\
\hline Fludioxonil & 0.04 & 40.00 & 30.00 & 4.00 & 100-fold under \\
\hline
\end{tabular}

Italic print indicates concentrations exceeding surrogate-MRLs. Comparisons were made to the lowest reported MRL 
if the samples had been analyzed with the appropriate methods [52].

\section{Origin of detected pesticides}

We assume that the main sources of pesticide residue contamination in our study were drifting during application or secondary drift via volatilization and/or dust from soil or plants after application [53, 54]. Of the 33 substances identified in the grass samples in the present study, 97\% were approved for use in fruit orchards and vineyards in Italy at the time of sampling [55]. Propiconazole and diphenylamine are not approved for fruit growing, but are approved for general agriculture and are additionally contained in wood preservatives. The origin of the two detected preservative agents (diphenylamine and 2-phenylphenol) is also most likely agricultural, as both are used for post-harvest treatments to control storage disease in apples and citrus fruits. In Italy, diphenylamine is used as an anti-scald agent to avoid skin browning [55]. Diphenylamine is also used for non-agricultural dyes.

Only 10 of the detected pesticides, or $30 \%$, have approval for non-professional users, nine fungicides, and one insecticide [55-57]. Therefore, we assume that the majority of residues in our samples very most likely derived from agricultural applications, though we cannot rule out contributions from other sources.

According to the official risk assessments, all detected residues (except the preservative-agent 2-phenyl-phenol, Table 1) are characterized by low volatility and thus are expected not to move more than a few meters beyond the application site [58]. However, our results suggest that evaporation from plant surfaces or particle drift may be significant sources for off-site contamination. It is important to point out that the European Food Safety Authority (EFSA) builds its risk assessment on expectations and modeling. Our data show that these models seem to underestimate the real-life situation and we, therefore, plead for a stricter application of the precautionary principle.

\section{Potential impact of pesticide residues on human health}

We assume that vegetables and fruits from nearby private gardens are as likely to be similarly contaminated by pesticide drift as the grass on public sites. Hence, we argue that the residue levels in grass samples might also be a valid indicator for overall contamination in public sites and private gardens.

Comparing residue levels in the grass with MRLs for lettuce, spinach, and strawberries, the levels for fluazinam and captan detected in this study, exceeded the surrogate MRLs 24-fold and 15-fold, respectively. Moreover, fluazinam is an endocrine active substance of category 2
[43] and captan is classified as a category 2 carcinogen, according to the EU pesticide database [56].

The multiple detections of fluazinam on three sites on the following sampling dates (spring and summer) at the end of May and the end of July with decreasing concentrations indicate a possible persistence of this residue. The half-life of fluazinam is up to 69 days [59] (Table 1) and the concentration decline from spring to summer was $80 \%$ (Fig. 3). Residues of the fungicides captan and dodine did not decline and their half-lives are only between 3 and 5 days, indicating that both are less persistent and that the higher concentrations detected in summer occurred through repeated pesticide application (Fig. 3).

Generally, residue concentrations in grass samples were low, but the year-round detection and the reported contamination of the last years $[12,27,28]$ indicate chronic exposure of humans and the environment. Among the detected pesticides, chlorpyrifos and chlorpyrifos-methyl are the most hazardous. Residues of these chemicals were detected in the grass samples of 2018 and in samples from earlier years [12, 27, 28]. Low doses of chlorpyrifos have been shown to lead to brain anomalies in fetuses and children [60], and to affect locomotor activity, behavior, and neurotransmitter systems in rats [61]. Recently a study [62] re-evaluated the low dose effects of chlorpyrifos in developmental neurotoxicity and corrected the misleading results of the original assessment [63]; meanwhile, these two insecticides are banned in the EU.

Overall, 25 of the 33 identified compounds are EDAs $[43,64]$, which were present in $96 \%$ of the investigated sites, while in $53 \%$ of them, EA substances were detected all year round. Endocrine disruptive compounds frequently exhibit non-monotonic dose-response relationships and, therefore, can be effective in concentrations several orders of magnitude below common residue thresholds [65]. Relative to their body weight, children inhale more air, drink more, and eat more food than adults, and some activities of children on playgrounds are likely to bring them in contact with contaminants present in the grass or sand [24, 66]. Endocrine active pesticides interfere with oestrogen or androgen receptors [1] and have been linked to an increased risk of thyroid, breast, and prostate cancer $[1,67]$. Simultaneous exposure to a variety of pesticides might also trigger synergistic effects [68], which are extremely difficult to examine in risk assessments [69]. Due to the low-dose effect, the nonmonotonic dose-response relationship, and the interaction of EDCs with endogenous hormones or other EDCs, it is questionable whether a low dose can ever be considered safe $[45,65]$. Moreover, EDCs can cause multigenerational effects $[70,71]$ even in grandchildren of exposed pregnant women [72]. 
Exposure of pregnant women and children to endocrine active pesticides-as were detected in our grass samples-and/or their metabolites have been described in several publications. For example, di-ethyl phosphate and 3,5,6-trichloro-2-pyridinol, both metabolites of chlorpyrifos and chlorpyrifos-methyl, were detected in urine samples from children [73] and hair samples from pregnant women $[74,75]$, as well as cypermethrin, cyprodinil, difenoconazole, imidacloprid, oxadiazon, penconazole, propiconazole, pyraclostrobin, pyrimethanil, tebuconazole, tetraconazole, thiacloprid and zoxamid $[74,76]$. Many of the EDCs are fungicides-in this study $75 \%$ - which is also the most prevalent group of detected residues in the current sites. In the European Union, fungicide sales represent more than $40 \%$ of total pesticide sales, and in areas dominated by fruit growing, such as vineyard regions, fungicides account for more than $90 \%$ of all pesticide applications [77].

Fungicides such as propiconazole and tebuconazole have also been identified as potential human health risks by exposure through drinking water [78]. Indeed, contamination of surface water within the study area had been reported for the same pesticides and at similar concentrations as in grass samples from the public sites investigated [79].

Multiple pesticide contamination occurred on 19 sites at least once during the entire year. The effect of mixtures of active compounds and their specific formulations/additives is still not clear. Exposure due to pesticide drift raises the issue of multiple exposures from various sources [80] and the still unknown extent thereof. It is obvious that people living in the study area of this survey are simultaneously exposed to the same pesticides in commercial food, vegetables, fruits, and herbs from private gardens, as well as through inhalation of contaminated air.

Plant protection products consist, besides the active compounds, of specific formulations to enhance the effect of the ingredients. It is likely, for instance, that formulations on tween-basis can have an influence on the mobilization, bioavailability, and bioaccumulation of organochlorine contaminants and its metabolites [81, 82]. However, the concealment of the full list of ingredients in formulations makes a detailed investigation impossible.

\section{Impact on the environment}

Besides affecting human health, many of the detected pesticides have a proven impact on various non-target organisms and are in general a driving factor in biodiversity decline [83]. Non-target effects of pesticides affect soil biota [84-86], bees [87, 88], and other organisms important for the functioning of the agroecosystems [89].
A recent biodiversity assessment conducted in the same region as the presented study showed that butterflies are endangered through pesticide exposure [90].

We intended to estimate the association between environmental factors and pesticide residues in public sites, as we did in our previous study [12]. Due to a nearly three-fold higher number of different fungicides detected in spring 2018 compared to our previous study [12] and a higher proportion of public sites contaminated with fungicides, we hypothesized that such findings could relate to the higher rainfall in 2018. However, the relationship between precipitation and detected fungicide residues was not significant, pointing to multifactorial influences.

One public site was without any pesticide residue throughout the year, even though the site is located only $40 \mathrm{~m}$ from the closest agricultural area. However, we know from the previous study [12] that, besides chemical drift, the characteristics of the pesticides applied, as well as the prevailing wind direction and wind speed, may have affected the contamination of these public sites.

Our results show that even a distance of more than $100 \mathrm{~m}$ to agricultural sites does not lower the contamination level significantly (Additional file 1: Figure S1) and the relationship between residue load and distance is not linear (Additional file 1: Figure S2). Therefore, an evaluation of the extent of exposure requires further studies and a subsequent risk assessment.

There are already sufficient arguments to ban or at least drastically reduce pesticide application. The most important arguments therefor concerning human and environmental health, sustainability, and costs. The impact of chronic pesticide exposure on human health and the environment is proven [1,89]. All in all, the health costs to the EU caused by endocrine active compounds, mainly pesticides, have been estimated at more than $€ 150$ billion annually [91, 92]. However, sustainable and ecological agriculture is possible and economically. It generates farm incomes exceeding those from conventional and industrial farms, providing more employment and thus supporting regional economies by using less fossil fuel and contributing to preserving biodiversity [93].

\section{Conclusions}

Our findings suggest that pesticide contamination of public sites in intensively managed agricultural areas is a year-round potential health issue, in particular for the most vulnerable groups of society, including infants and pregnant women. The long-term effects of exposure to such contamination are entirely unknown.

Our results are particularly critical because the majority of the detected pesticides are known EDAs and several samples contained hazardous compounds such as 
chlorpyrifos (recently banned because of its neurotoxicity) or captan (classified in the EU as a "suspected human carcinogen").

It is likely that other non-crop sites within intensively managed agricultural areas such as private gardens, nature conservation areas, or fields of organic farms are contaminated in a similar way. This is an aspect that is rarely addressed in the scientific and public debate. Our findings also suggest that the guidelines of the European Food Safety Authority (EFSA) concerning the exposure of operators, workers, residents, and bystanders [58] are not sufficiently protective, because they base their risk assessment on volatility, disregarding other mechanisms of drift, e.g., via particulate matter. Therefore, we suggest to include field studies, such as our study, in the risk assessment.

Hence, we recommend an overall reduction of pesticide use and improvements in agricultural practices as precautionary measures to protect human and environmental health from uncontrolled pesticide exposure.

\section{Supplementary Information}

The online version contains supplementary material available at https://doi. org/10.1186/s12302-020-00446-y.

Additional file 1. Additional figures and tables.

\section{Abbreviations}

EDs: Endocrine disruptors; EDA: Endocrine active; EDC: Endocrine disruptive compounds; MRL: Maximum residue limit/level; IQR: Interquartile range.

\begin{abstract}
Acknowledgements
We are grateful to the environmental medicine department of the South Tyrolean Medical Service (Departement für Gesundheitsvorsorge - Betriebliche Sektion für Umweltmedizin des Südtiroler Sanitätsbetriebs) of the Autonomous Province Bolzano-South Tyrol for sampling and analysing the data and for providing the data. We gratefully acknowledge the suggestions of three anonymous reviewers for improving this manuscript and thank Claire Robinson for English language editing services. Open access funding was provided by the University of Natural Resources and Life Sciences Vienna (BOKU).
\end{abstract}

\section{Authors' contributions}

$\mathrm{CL}$ planned and conducted data analyses, generated tables, and graphs and did the literature search. JGZ, PC, SP, and FB provided literature and substantial expert knowledge. $\mathrm{KH}$ organized the study data, did the preliminary data analysis, organized explanatory data and provided literature. All authors read and approved the final manuscript.

\section{Funding}

Several NGOs funded the statistical analysis and writing of the study. The funders had no role in study design, data collection, and analysis, decision to publish, or preparation of the manuscript.

\section{Availability of data and materials}

The datasets used and/or analysed during the current study are available from the corresponding author on reasonable request.

\section{Ethics approval and consent to participate}

Not applicable.

\section{Consent for publication}

Not applicable.

\section{Competing interests}

The authors declare no financial and non-financial competing interests.

\section{Author details}

${ }^{1}$ Pesticide Action Network Europe, 67 Rue de la Pacification, 1000 Brussels, Belgium. ${ }^{2}$ Cesare Maltoni Cancer Research Center (CMCRC), Ramazzini Institute (RI), Via Saliceto, 3, Bentivoglio, 40010 Bologna, Italy. ${ }^{3}$ Pesticide Action Network Germany, Nernstweg 32, 22765 Hamburg, Germany. ${ }^{4}$ Institute of Zoology, University of Natural Resources and Life Sciences Vienna (BOKU), Gregor Mendel Straße 33, 1180 Vienna, Austria.

Received: 19 August 2020 Accepted: 8 December 2020

Published online: 06 January 2021

\section{References}

1. MnifW, Hassine AlH, Bouaziz A et al (2011) Effect of endocrine disruptor pesticides: a review. Int J Environ Res Public Health 8:2265-2303

2. Zhang W (2018) Global pesticide use: profile, trend, cost/benefit and more. Proc Int Acad Ecol Environ Sci 8:1-27

3. Sharma A, Kumar V, Shahzad B et al (2019) Worldwide pesticide usage and its impacts on ecosystem. SN Appl Sci 1:1446. https://doi. org/10.1007/s42452-019-1485-1

4. Benbrook CM (2016) Trends in glyphosate herbicide use in the United States and globally. Environ Sci Eur 28:3. https://doi.org/10.1186/s1230 2-016-0070-0

5. Egendorf SP, Gailey AD, Schachter AE, Mielke HW (2020) Soil toxicants that potentially affect children's health. Curr Probl Pediatr Adolesc Health Care 50:100741. https://doi.org/10.1016/j.cppeds.2019.100741

6. Zaller JG (2020) Daily poison: pesticides_-an underestimated danger. Springer International Publishing, Cham

7. European Commission Statistical Office-Eurostat (2019) Agri-environmental indicator-consumption of pesticides

8. European Commission Statistical Office-Eurostat (2019) Data explorer. https://appsso.eurostat.ec.europa.eu/nui/submitViewTableAction.do. Accessed 21 May 2020

9. European Commission Statistical Office-Eurostat (2017) Agricultural production-crops

10. Istat (2018) Tavola 07: Principi attivi contenuti nei prodotti fitosanitari per ettaro di superficie trattabile (in chilogrammi). Dettaglio per regione - Anno 2017 -. http://agri.istat.it/jsp/dawinci.jsp?q=pl07a0000010000 012000\&an $=2017 \& \mathrm{ig}=1 \& \mathrm{ct}=428 \& \mathrm{id}=3 \mathrm{~A} \% 7 \mathrm{C} 45 \mathrm{~A} \% 7 \mathrm{C} 66 \mathrm{~A} \% 7 \mathrm{C} 67 \mathrm{~A}$. Accessed 30 Jan 2019

11. Bukalasa JS, Brunekreef B, Brouwer M et al (2017) Proximity to agricultural fields as proxy for environmental exposure to pesticides among children: the PIAMA birth cohort. Sci Total Environ 595:515-520. https://doi. org/10.1016/j.scitotenv.2017.03.269

12. Linhart C, Niedrist GH, Nagler M et al (2019) Pesticide contamination and associated risk factors at public playgrounds near intensively managed apple and wine orchards. Environ Sci Eur 31:28. https://doi.org/10.1186/ s12302-019-0206-0

13. Farha W, Abd El-Aty AM, Rahman MdM et al (2016) An overview on common aspects influencing the dissipation pattern of pesticides: a review. Environ Monit Assess 188:693. https://doi.org/10.1007/s1066 1-016-5709-1

14. Mattei C, Wortham H, Quivet E (2018) Heterogeneous atmospheric degradation of pesticides by ozone: influence of relative humidity and particle type. Sci Total Environ 625:1544-1553. https://doi.org/10.1016/j. scitotenv.2018.01.049

15. Navarro S, Vela N, Navarro G (2007) Review. An overview on the environmental behaviour of pesticide residues in soils. Span J Agric Res 3:357-375

16. Pereira VJ, da Cunha JP, de Morais TP et al (2016) Physical-chemical properties of pesticides: concepts, applications, and interactions with the environment. Biosci J. https://doi.org/10.14393/BJ-v32n3a2016-31533

17. Sapcanin A, Cakal M, Imamovic B et al (2016) Herbicide and pesticide occurrence in the soils of children's playgrounds in Sarajevo, Bosnia and Herzegovina. Environ Monit Assess 188:450. https://doi.org/10.1007/ s1 0661-016-5463-4 
18. Meeker JD (2012) Exposure to environmental endocrine disruptors and child development. Arch Pediatr Adolesc Med 166:E1-E7. https://doi. org/10.1001/archpediatrics.2012.241

19. Di Ciaula A, Portincasa P (2019) The role of environmental pollution in endocrine diseases. In: Portincasa P, Frühbeck G, Nathoe HM (eds) Endocrinology and systemic diseases. Springer International Publishing, Cham, pp 1-31

20. Kahn LG, Philippat C, Nakayama SF et al (2020) Endocrine-disrupting chemicals: implications for human health. Lancet Diabetes Endocrinol 8:703-718. https://doi.org/10.1016/\$2213-8587(20)30129-7

21. Encarnação T, Pais AA, Campos MG, Burrows HD (2019) Endocrine disrupting chemicals: impact on human health, wildlife and the environment. Sci Prog 102:3-42. https://doi.org/10.1177/0036850419826802

22. Muñoz-Quezada MT, Lucero BA, Barr DB et al (2013) Neurodevelopmental effects in children associated with exposure to organophosphate pesticides: a systematic review. NeuroToxicology 39:158-168. https://doi. org/10.1016/j.neuro.2013.09.003

23. Liu J, Schelar E (2012) Pesticide exposure and child neurodevelopment: summary and implications. Workplace Health Saf 60:235-242. https://doi. org/10.1177/216507991206000507

24. Pascale A, Laborde A (2020) Impact of pesticide exposure in childhood. Rev Environ Health. https://doi.org/10.1515/reveh-2020-0011

25. European Commission Statistical Office-Eurostat (2017) Agricultural production-crops. http://ec.europa.eu/eurostat/statistics-explained/index .php/Agricultural_production_-_crops. Accessed 20 Aug 2004

26. Villiot A, Chrétien E, Drab-Sommesous E et al (2018) Temporal and seasonal variation of atmospheric concentrations of currently used pesticides in Champagne in the centre of Reims from 2012 to 2015. Atmos Environ 174:82-91. https://doi.org/10.1016/j.atmosenv.2017.11.046

27. Clausing P (2016) Bewertung von Pestizidrückständen in Pflanzenmaterial (Grasproben vom 28.5.2016) aus Südtirol. Hamburg

28. Clausing P (2017) Grasproben, Südtirol 2017 Bewertung von Pestizidrückständen in Pflanzenmaterial (Proben vom 16.-23.5.2017). Hamburg

29. Geier G, Peterlin D, Tartarotti P, Rastner L (2018) Historische Daten | Wetter Südtirol | Autonome Provinz Bozen - Südtirol. http://wetter.provinz.bz.it/ historische-daten.asp. Accessed 29 Oct 2018

30. European Food Safety Authority (EFSA), Medina-Pastor P, Triacchini G (2020) The 2018 European Union report on pesticide residues in food. EFSA J 18:e06057. https://doi.org/10.2903/j.efsa.2020.6057

31. Autonome Provinz Bozen - Südtirol, Südtiroler Sanitätsbetrieb (2020) Bürgerzugang | Südtiroler Sanitätsbetrieb. https://www.sabes.it/de/trans parente-verwaltung/buergerzugang.asp\#accept-cookies. Accessed 4 Jun 2020

32. Wegher $L$ (2019) Monitoring der Pflanzenschutzmittelrückstände auf öffentlichen Spielplätzen 2018-2019. Departement für Gesundheitsvorsorge des Südtiroler Sanitätsbetriebs- Betriebliche Sektion für Umweltmedizin

33. Anastassiades M, Lehotay SJ, Štajnbaher D, Schenck FJ (2003) Fast and easy multiresidue method employing acetonitrile extraction/partitioning and "dispersive solid-phase extraction" for the determination of pesticide residues in produce. J AOAC Int 86:412-431. https://doi.org/10.1371/ journal.pone.0029268

34. PN-EN 156622008 (2008) Foods of plant origin—determination of pesticide residues using GC-MS and/or LC-MS(/MS) following acetonitrile extraction/partitioning and cleanup by dispersive SPE-QuEChERS-method

35. Departement für Gesundheitsvorsorge des Südtiroler SanitätsbetriebsBetriebliche Sektion für Umweltmedizin, Wegher L (2019) Monitoring der Pflanzenschutzmittelrückständeauf öffentlichen Spielplätzen 2018-2019. Bozen

36. RStudio Team (2020) RStudio: integrated development environment for R. RStudio, PBC, Boston

37. Højsgaard S, Halekoh U (2020) doBy: groupwise statistics, LSmeans, linear contrasts, utilities

38. Revelle W (2020) psych: procedures for psychological, psychometric, and personality research

39. Long JA (2020) jtools: analysis and presentation of social scientific data

40. Pohlert T (2018) PMCMR: calculate pairwise multiple comparisons of mean rank sums

41. Wickham H, François R, Henry L, et al (2020) dplyr: a grammar of data manipulation
42. White RR and $H$ (2020) tigerstats: $R$ functions for elementary statistics

43. European Commission (2016) Defining criteria for identifying endocrine disruptors in the context of the implementation of the plant protection products regulation and biocidal products regulation. Brussels

44. WHO/UNEP (2013) State of the science of endocrine disrupting chemicals-2012

45. Munn Sharon, Goumenou Marina, Institute for Health and Consumer Protection (2013) Thresholds for endocrine disrupters and related uncertainties: report of the Endocrine Disrupters Expert Advisory Group. Publications Office

46. Pesticide Action Network (2016) PAN pesticide database. Oakland, CA

47. Miersma NA, Pepper CB, Anderson TA (2003) Organochlorine pesticides in elementary school yards along the Texas-Mexico border. Environ Pollut 126:65-71. https://doi.org/10.1016/S0269-7491(03)00126-X

48. Burrows HD, Canle ML, Santaballa JA, Steenken S (2002) Reaction pathways and mechanisms of photodegradation of pesticides. J Photochem Photobiol B 67:71-108. https://doi.org/10.1016/s1011-1344(02)00277-4

49. Katagi T (2004) Photodegradation of pesticides on plant and soil surfaces. Rev Environ Contam Toxicol 182:1-189. https://doi. org/10.1007/978-1-4419-9098-3 1

50. Linhard D, Unterkircher C, Eder H, Potuschak S (2018) Pestizidtest: Ackerrandstreifen. Vienna, Austria

51. Hofmann F, Kruse-Plaß M, Schlechtriemen U, Wosniok W (2020) Eine deutschlandweite Studie zur Ermittlung der Belastung der Luft mit Hilfe von technischen Sammlern, Bienenbrot, Filtern aus Be- und Entlüftungsanlagen und Luftgüte-Rindenmonitoring hinsichtlich des Vorkommens von Pestizid-Wirkstoffen, insbesondere Glyphosat. TIEM Integrierte Umweltüberwachung GbR and Bündnis für eine Enkeltaugliche Landwirtschaft e.V., Dortmund

52. Koskinen WC, Marek LJ, Hall KE (2016) Analysis of glyphosate and aminomethylphosphonic acid in water, plant materials and soil. Pest Manag Sci 72:423-432. https://doi.org/10.1002/ps.4172

53. Deziel NC, Friesen MC, Hoppin JA et al (2015) A review of nonoccupational pathways for pesticide exposure in women living in agricultural areas. Environ Health Perspect 123:515-524. https://doi.org/10.1289/ ehp. 1408273

54. Ward MH, Lubin J, Giglierano J et al (2006) Proximity to crops and residential exposure to agricultural herbicides in lowa. Environ Health Perspect 114:893-897. https://doi.org/10.1289/ehp.8770

55. Ministero della Salute (2020) Prodotti fitosanitari - Risultato della ricerca della banca dati dei prodotti fitosanitari. In: Banca Dati Dei Prodotti Fitosanit. http://www.fitosanitari.salute.gov.it/fitosanitariwsWeb_new/ FitosanitariServlet. Accessed 23 Nov 2020

56. PPDB Management Team, University of Hertfordshire (2016) IUPAC PPDB — pesticides properties data base. In: Pestic Prop Data Base. https:// sitem.herts.ac.uk/aeru/iupac/index.htm. Accessed 16 July 2020

57. Agrios-Arbeitsgruppe für integrierten Obstbau in Südtirol (2018) AGRIOS-Programm 2018

58. European Food Safety Authority (2014) Guidance on the assessment of exposure of operators, workers, residents and bystanders in risk assessment for plant protection products. EFSA J 12:3874. https://doi. org/10.2903/j.efsa.2014.3874

59. Fantke P, Gillespie BW, Juraske R, Jolliet O (2014) Estimating half-lives for pesticide dissipation from plants. Environ Sci Technol 48:8588-8602. https ://doi.org/10.1021/es500434p

60. Rauh VA, Perera FP, Horton MK et al (2012) Brain anomalies in children exposed prenatally to a common organophosphate pesticide. Proc Natl Acad Sci USA 109:7871-7876. https://doi.org/10.1073/pnas.1203396109

61. Perez-Fernandez C, Morales-Navas M, Guardia-Escote L et al (2020) Postnatal exposure to low doses of Chlorpyrifos induces long-term effects on 5C-SRTT learning and performance, cholinergic and GABAergic systems and BDNF expression. Exp Neurol 330:113356. https://doi.org/10.1016/j. expneurol.2020.113356

62. Mie A, Rudén C, Grandjean P (2018) Safety of safety evaluation of pesticides: developmental neurotoxicity of chlorpyrifos and chlorpyrifosmethyl. Environ Health 17:77. https://doi.org/10.1186/s12940-018-0421-y

63. Hobermann AM (1998) Developmental neurotoxicity study of chlorpyrifos administered orally via gavage to $\mathrm{Crl}: \mathrm{CD}^{\circledR}{ }^{\circledR}$ R VAF/Plus ${ }^{\circledR}$ presumed pregnant rats. Argus Research Laboratories Inc, Horsham

64. European Commission (2017) EU Pesticides database-European Commission. In: Online. http://ec.europa.eu/food/plant/pesticides/ 
eu-pesticides-database/public/?event=activesubstance.detail\&langu age $=E N \&$ selectedID $=891$. Accessed 22 July 2018

65. Vandenberg LN, Colborn T, Hayes TB et al (2012) Hormones and endocrine-disrupting chemicals: low-dose effects and nonmonotonic dose responses. Endocr Rev 33:378-455. https://doi.org/10.1210/er.2011-1050

66. Moya J, Bearer CF, Etzel RA (2004) Children's behavior and physiology and how it affects exposure to environmental contaminants. Pediatrics 113:996-1006

67. El-Zaemey S, Heyworth J, Fritschi L (2013) Noticing pesticide spray drift from agricultural pesticide application areas and breast cancer: a case-control study. Aust N Z J Public Health 37:547-555. https://doi. org/10.1111/1753-6405.12111

68. Laetz CA, Baldwin DH, Collier TK et al (2009) The synergistic toxicity of pesticide mixtures: implications for risk assessment and the conservation of endangered Pacific salmon. Environ Health Perspect 117:348-353. https://doi.org/10.1289/ehp.0800096

69. Damalas CA, Eleftherohorinos IG (2011) Pesticide exposure, safety issues, and risk assessment indicators. Int J Environ Res Public Health 8:14021419. https://doi.org/10.3390/ijerph8051402

70. Segal TR, Giudice LC (2019) Before the beginning: environmental exposures and reproductive and obstetrical outcomes. Fertil Steril 112:613621. https://doi.org/10.1016/j.fertnstert.2019.08.001

71. Ho S-M, Cheong A, Adgent MA et al (2017) Environmental factors, epigenetics, and developmental origin of reproductive disorders. Reprod Toxicol Elmsford N 68:85-104. https://doi.org/10.1016/j.reprotox.2016.07.011

72. Gaspari L, Paris F, Cassel-Knipping N et al (2020) Diethylstilbestrol exposure during pregnancy with primary clear cell carcinoma of the cervix in an 8-year-old granddaughter: a multigenerational effect of endocrine disruptors? Hum Reprod Oxf Engl. https://doi.org/10.1093/humrep/ deaa267

73. Pirard C, Remy S, Giusti A et al (2020) Assessment of children's exposure to currently used pesticides in Wallonia, Belgium. Toxicol Lett 329:1-11. https://doi.org/10.1016/j.toxlet.2020.04.020

74. Béranger R, Hardy EM, Binter A-C et al (2020) Multiple pesticides in mothers' hair samples and children's measurements at birth: results from the French national birth cohort (ELFE). Int J Hyg Environ Health 223:22-33. https://doi.org/10.1016/j.ijheh.2019.10.010

75. Béranger R, Hardy EM, Dexet C et al (2018) Multiple pesticide analysis in hair samples of pregnant French women: results from the ELFE national birth cohort. Environ Int 120:43-53. https://doi.org/10.1016/j.envin t.2018.07.023

76. Iglesias-González A, Hardy EM, Appenzeller BMR (2020) Cumulative exposure to organic pollutants of French children assessed by hair analysis. Environ Int 134:105332. https://doi.org/10.1016/j.envint.2019.105332

77. Zubrod JP, Bundschuh M, Arts G et al (2019) Fungicides: an overlooked pesticide class? Environ Sci Technol 53:3347-3365. https://doi. org/10.1021/acs.est.8b04392

78. Creusot N, Casado-Martinez C, Chiaia-Hernandez A et al (2020) Retrospective screening of high-resolution mass spectrometry archived digital samples can improve environmental risk assessment of emerging contaminants: a case study on antifungal azoles. Environ Int 139:105708. https://doi.org/10.1016/j.envint.2020.105708

82. ISPRA, Paris P (2018) Rapporto nazionale pesticidi nelle acque dati 2015-2016. ISPRA, Roma

80. European Commission (2019) Farm to fork strategy — for a fair, healthy and environmentally-friendly food system. In: Food Saf - Eur Comm. https ://ec.europa.eu/food/farm2fork_en. Accessed 12 June 2020

81. Neitsch J, Schwack W, Weller P (2016) Modern agrochemicals influence bioaccumulation of incurred DDT soil residues in pumpkins - residue risk or a chance for phytoremediation? J Agric Food Chem 64:7445-7451. https://doi.org/10.1021/acs.jafc.6b03168

82. Neitsch J, Schwack W, Weller P (2018) Modern agrochemicals influence bioaccumulation of incurred DDT soil residues in pumpkins-residue risk or a chance for phytoremediation? Int J Res Environ Sci 4:13-23
83. Brühl CA, Zaller JG (2019) Biodiversity decline as a consequence of an inappropriate environmental risk assessment of pesticides. Front Environ Sci. https://doi.org/10.3389/fenvs.2019.00177

84. Burrows LA, Edwards CA (2002) The use of integrated soil microcosms to predict effects of pesticides on soil ecosystems. Eur J Soil Biol 38:143-161. https://doi.org/10.1016/S1164-5563(02)01153-6

85. Hoesel W, Dorn VM, Tiefenbacher A et al (2017) Single and combined effects of pesticide seed dressings and herbicides on earthworms, soil microorganisms, and litter decomposition. Front Plant Sci 8:215. https:// doi.org/10.3389/fpls.2017.00215

86. Zaller JG, Cantelmo C, Santos GD et al (2018) Herbicides in vineyards reduce grapevine root mycorrhization and alter soil microorganisms and the nutrient composition in grapevine roots, leaves, xylem sap and grape juice. Environ Sci Pollut Res 25:23215-23226. https://doi.org/10.1007/ s11356-018-2422-3

87. Sanchez-Bayo F, Goka K (2014) Pesticide residues and bees-a risk assessment. PLoS ONE 9:e94482. https://doi.org/10.1371/journal.pone.0094482

88. Sánchez-Bayo F, Goulson D, Pennacchio F et al (2016) Are bee diseases linked to pesticides? - a brief review. Environ Int 89-90:7-11. https://doi. org/10.1016/j.envint.2016.01.009

89. Zaller JG, Brühl CA (2019) Editorial: non-target effects of pesticides on organisms inhabiting agroecosystems. Front Environ Sci 7:75. https://doi. org/10.3389/fenvs.2019.00075

90. Tarmann GM (2018) Kartierung der aktuellen Verbreitung des Felsenfalters (Berghexe) (Chazara briseis) und von Widderchen (Lepidoptera, Zygaenidae) im Gemeindegebiet von Mals (Vinschgau, Südtirol) als Grundlage für eine nachhaltige Erhaltung der Arten. Heimatpflegeverein der Gemeinde Mals

91. Trasande L, Zoeller RT, Hass U et al (2015) Estimating burden and disease costs of exposure to endocrine-disrupting chemicals in the European Union. J Clin Endocrinol Metab 100:1245-1255. https://doi.org/10.1210/ jc.2014-4324

92. Trasande L, Zoeller RT, Hass U et al (2016) Burden of disease and costs of exposure to endocrine disrupting chemicals in the European Union: an updated analysis. Andrology 4:565-572. https://doi.org/10.1111/ andr. 12178

93. van der Ploeg JD, Barjolle D, Bruil J et al (2019) The economic potential of agroecology: empirical evidence from Europe. J Rural Stud 71:46-61. https://doi.org/10.1016/j.jurstud.2019.09.003

94. European Food Safety Authority (2020) Renewal assessment reports (RARs)

95. (2020) WHO | Endocrine Disrupting Chemicals (EDCs). In:WHO. http:// www.who.int/ceh/risks/cehemerging2/en/. Accessed 2 June 2020

\section{Publisher's Note}

Springer Nature remains neutral with regard to jurisdictional claims in published maps and institutional affiliations.

\section{Submit your manuscript to a SpringerOpen ${ }^{\circ}$ journal and benefit from:}

- Convenient online submission

- Rigorous peer review

- Open access: articles freely available online

- High visibility within the field

- Retaining the copyright to your article

Submit your next manuscript at $\boldsymbol{\nabla}$ springeropen.com 